\title{
EDITORIAL
}

\section{Concord, Conflict and Co-existence Religion and society in the Middle East and North Africa}

\section{$\mathrm{T}$} he current issue of Approaching Religion contains articles based on conference papers presented at the Third Finnish Colloquium on the Middle East and North African Studies, which was organised by The Finnish Institute in the Middle East (FIME) together with the Donner Institute, Åbo Akademi University and the Tampere Peace Research Institute, in Turku, 5-7 June, 2014. The theme of the conference - 'Concord, Conflict and Co-existence: Religion and Society in the Middle East and North Africa' - was as timely as ever in light of the societal upheavals, even turmoil, in many countries following the uprisings in North Africa and the Middle East. But as is well known, these themes are not relevant only in the contemporary world but equally from an historical perspective. They are as much a part of history as of today. There is something eternal in these Colloquium themes; that is why they are selected. They pose continuing challenges for scholars and intriguing fields of study for students.

One of The Colloquium's Plenary SEssions, 'People, politics, space and holiness in Jerusalem', successfully underpinned the objective of the Colloquium. Discussions, debates and presentations focused on the peoples, societies and religions of a region that is so rich in its diversity - whether one thinks in terms of its history, cultures, ethnicities, societies, tribes, or religions - not to speak of contemporary politics. The Colloquium theme facilitated an excellent multidisciplinary gathering and provided a networking forum for Finnish and foreign scholars working on the Middle East and North Africa. The articles accepted for this issue of Approaching Religion also mirror this theoretical and thematic complexity in an apt way. It spans the entire chronological array from ancient times until today; it deals with geographical areas from all corners of the Mediterranean, the Middle East and North Africa and it in- cludes theoretical and methodological contributions from such different perspectives as archaeology, exegetics, feminist theory and political studies.

FIME is an academic institute that focuses on the study of Middle Eastern cultures, religions, societies and classic and modern languages. The Institute supports Finnish research on the Middle East and cooperates with universities and research institutions in related fields of research and study. In the Middle East, the Institute is based in the historic Zeitouna House in the Old City of Damascus. Since 2013, however, the Institute has operated from an office established in Beirut, Lebanon. It also has a permanent representative in Cairo, Egypt. FIME initiated the Finnish Colloquiums as one of its primary activities in Finland, with a specific objective of strengthening its partnerships and enhancing Middle Eastern and North African studies in Finland. Importantly, the Colloquiums serve as bridge between the Middle East and Finland-based research communities. We are happy to be able to present the scholarly fruits of this co-operation in the current issue of Approaching Religion.

ARI KERKKÄNEN, Guest Editor RUTH ILLMAN, Editor

Ari Kerkkänen has a PhD in Semitic Languages and Cultures from the University of Helsinki. He currently works as Chief of Planning at the EU Police Mission in Afghanistan and is a visiting university researcher at the Tampere Peace Research Institute. He is the former director of the Finnish Institute in the Middle East. Email: ari.kerkkanen(at)uta.fi

Ruth Illman is a docent of comparative religion at Åbo Akademi University and the director of the Donner Institute for Research in Religious and Cultural History in Åbo, Finland. Her main research interests include religion and the arts, interreligious dialogue and contemporary Judaism. Her website is <www.abo.fi/forskning/ruth>. Email: rillman(at)abo.fi 